\title{
Immunohistochemical Findings in Active Vitiligo Including Depigmenting Lesions and Non-Lesional Skin
}

\author{
Flavia M.N.P. Aslanian ${ }^{*}, 1$, Rosangela A.M. Noé ${ }^{1}$, Daniela P. Antelo ${ }^{1}$, Rogerio E. Farias ${ }^{2}$, \\ Pranab K. Das ${ }^{3}$, Ibrahim Galadari ${ }^{4}$, Tullia Cuzzi ${ }^{1}$ and Absalom L. Filgueira ${ }^{1}$
}

'Dermatology Sector, Federal University of Rio de Janeiro-RJ, Brazil

${ }^{2}$ Department of Morphology, Federal University of Juiz de Fora-MG, Brazil

${ }^{3}$ Department of Pathology, Academical Medical Center, Amsterdam University, The Netherlands

${ }^{4}$ Dermatology Sector, United Arab Emirates University, UAE

\begin{abstract}
Background: The evidence that vitiligo is an autoimmune disease is supported by its association with autoimmune conditions, the presence of activated cytotoxic $\mathrm{T}$ lymphocytes in the lesions and melanocyte-specific circulating auto-antibodies. Some studies have indicated the normal-appearing skin being immune-targeted for latent melanocyte disappearance.

Method: We aimed to characterize immunohistologically the cellular infiltrate and to identify the distribution pattern of T and Langerhans cells (LCs) in the active border of depigmenting lesions and clinically normal skin of 22 patients with progressive non-segmental vitiligo, besides the cellular expression for the cutaneous lymphocyte-associated antigen (CLA), comparing to 10 controls.

Results: Immunohistochemical analyses showed an overall reduction of the number of CD1a+ cells, dermal increase of CD8 + T cells, and increase of the epidermal CD3 + T cells number in the active border of lesions. Surprisingly, those cellular changes were also observed in clinically pigmented skin. However, a significant intra-epidermal infiltration of CD8 $+\mathrm{T}$ cells was evident only within active border biopsies. The CLA + cells were not significantly increased in the patients' skin.

Conclusions: The findings of this study suggest an extensively immune-committed skin in active vitiligo, mainly characterized by overall scarcity of CD1a+ cells and dermal increase of CD8+ cells even in apparently normal skin, in addition to the epidermal infiltrate of $\mathrm{CD} 8+\mathrm{T}$ cells in the depigmenting areas. This report further supports that some CD8+ T and LCs cells play a pivotal role in the process of melanocyte loss, and strengthens an auto-immune hypothesis for vitiligo.
\end{abstract}

Keywords: Vitiligo, immunohistochemistry, lymphocytes, melanocytes, autoimmunity.

\section{INTRODUCTION}

Vitiligo is characterized by the development of white patches, resulting from the loss of melanocytes. The natural course of the disease remains largely unknown. However, the disease frequently progresses in exposed areas of the skin, mainly in the face, which affects the appearance of the individual considerably [1]. Considered generally a cosmetic problem, this pigmentary disorder has repercussions on the quality of life of the patients, that might improve following the degree of repigmentation achieved by the treatment [2].

There are several hypotheses regarding the etiology of vitiligo such as the neural, autocytotoxic, genetic and the immunological [3]. However, the growing findings suggest that it is an autoimmune disease, because of its association with other autoimmune diseases $[4,5]$, anti-melanocytes and other organ-specific auto-antibodies [6]. Immunogenetic

*Address correspondence to this author at the Dermatology Sector, Federal University of Rio de Janeiro (UFRJ), Brazil; Tel/Fax: +5521-25622580;

E-mail: fpretti@cyberwal.com.br phenomena seem to correlate with the duration of vitiligo [7]. Recently, Jin et al. [8] have confirmed its association with the NALP1, a candidate gene on chromosome $17 \mathrm{p} 13$. NALP1 variants can result in the activation of interleukin1(beta), whose levels are elevated in patients with generalized vitiligo [9], suggesting the involvement of this pathway in the pathogenesis of the disease.

There is, at present, compelling evidence that the role of the cellular immunity is an important phenomenon in the development of vitiligo [7]. Intraepidermal infiltrates of CD8-CLA (cutaneous lymphocyte-associated antigen) $+\mathrm{T}$ lymphocytes have been observed in depigmented and perilesional areas, particularly in regions juxtaposed to melanocytes, in active disease, by immunohistochemical methods [10-12]. This suggests a T-cell mediated immune reaction [7], and the possible destruction of melanocytes by $\mathrm{T}$ cytotoxic lymphocytes [12, 13]. Moreover, elevated frequencies of circulating Melan A-specific CD8-CLA+ T lymphocytes $\left(\mathrm{A}^{*} 0201\right.$ restricted) were observed in the peripheral blood of vitiligo patients, implicating a direct melanocyte specific $T$ cell attack [14]. The presence of $T$ 
cells expressing the CLA in active vitiligo lesions suggests a selective migration of these cells from the peripheral circulation towards the afflicted skin and its participation in the immune response $[10,11,15,16]$. Some authors observed an increased expression of CLA in $\mathrm{T}$ cells in perilesional skin compared to non-lesional skin of patients with active vitiligo [10, 11]. In addition, the vitiligo-like hipopigmentation in some patients with melanoma further supports the pivotal role of T cells against melanocytes in the etiopathogenesis of common vitiligo [17, 18].

Interestingly, the Koebner phenomenon is also observed in the non-lesional skin of vitiligo patients, which refers to the appearance of clinical lesions in "uninvolved skin" as a result of mechanical trauma [19]. In psoriasis, there is an increase of activated intraepidermal $\mathrm{T}$ cell $(\mathrm{CD} 8+$ and ICAM-1+) also formed in the non-lesional site of the patients' skin [20]. Such findings suggested that the clinically uninvolved skin of psoriatic patients presents a constitutively activated state which favors the migration of a selective population of $\mathrm{T}$ cells to precipitate the disease. In an analogous manner, we have recently found a reduced pigmentation of the basal layer in the apparently normal skin in $50 \%$ of vitiligo patients, indicative of an involvement of different sites of skin, and strengthening the participation of autoimmune mechanisms in the disease [21]. Whether or not such reduced pigmentation will evolve with the presence of some intraepidermal lymphocytes and the eventual appearance of clinically depigmented skin remains unknown. An interesting study [12] showed an intraepidermal infiltration of $\mathrm{T}$ cells located in parallel with areas of melanocytes loss, synonymed as "microdepigmentation" in the non-lesional skin in vitiligo, which seems to corroborate our preliminary findings of cutaneous immune reaction even in the clinically pigmented skin [21].

The aim of the present study was to analyze further immunohistochemical findings in the non-lesional skin and active border of lesions in patients affected by nonsegmental vitiligo, focusing on infiltrate of lymphocytes, Langerhans cells, and CLA expression, and to compare them with the skin of normal controls. What is the degree of cutaneous immunological commitment of the integument in the disease? What are the main differences between the active border and the non-lesional skin regarding the histological point of view and the cutaneous immune system? Perhaps the answers to these questions provide some advance in the knowledge of vitiligo etiopathogenesis.

\section{MATERIALS AND METHODOLOGY}

\section{Patients}

Twenty two patients with active generalized vitiligo and 10 matched (by sex and age) normal controls were selected from the Photodermatology Unit in the hospital of the Federal University of Rio de Janeiro-Brazil. Their ages ranged from 24 to 64 (mean age 43.5, SD 11.43), being 18 females and 4 males. The disease duration ranged from 1 to 50 years (mean $19.77 \pm$ SD15.91). Regarding the phototype, the patients belonged to: phototype III-5 patients $(22.7 \%)$; phototype IV- 11 patients (50\%); phototype V-6 patients $(27.3 \%)$. Most patients presented an involved body area larger than $20 \%$ (13 cases- $59.1 \%$ ). The control group consisted of 10 healthy individuals, without any history of auto-immune or related diseases, being 2 males and 8 females with an age range from 22 to 55 years old (mean age 38.9, SD 12.52).

We considered those as having active disease, who had presented an increase of the lesions in size and/or number, and/or Koebner phenomenon within the 3 months prior to participation [12]. Patients who had presented spontaneous repigmentation or received any treatment within that period were excluded.

All included individuals signed a detailed institutionallyapproved consent form (written). Ethical permission was given by the respective Ethical Committee and the study was in accordance with the Helsinki Declaration.

\section{Skin Biopsies}

Five-millimeter skin biopsies were obtained from the clinically normal skin (group A), and active border including non-lesional and adjacent lesional skin (group B), in vitiligo patients. Likewise, skin specimens of healthy controls were resected (group C). In groups $\mathrm{A}$ and $\mathrm{C}$, the chosen area for the biopsies was the back (with at least $5 \mathrm{~cm}$ distance from the depigmented sites and less visible). In group B, the chosen areas for the biopsies were depigmenting lesions in the upper limbs. All the biopsied specimens were split into 2 equal parts. The active border biopsies included lesional and non-lesional skin in both fragments (transversal cut to the limit between lesional and non-lesional skin). One half of the fragment was prepared conventionally for histological studies using haematoxylin-eosin and Fontana-Masson silver stain [21]. The other halves were paraffin-embedded, from which histological sections (four microns) were obtained and stained for immunohistochemical analysis, using retrieval technique, recommended by the manufacturer of the antibody in question (as formalin-fixed skin biopsies require antigen retrieval for most of the researched epitopes).

\section{Immunohistochemistry}

The composition of the inflammatory infiltrate in the skin biopsies was analyzed using reactive antibodies directed against $\mathrm{CD} 3+, \mathrm{CD} 4+$ and $\mathrm{CD} 8+\mathrm{T}$ lymphocytes, and against Langerhans cells $(\mathrm{CD} 1 \mathrm{a}+)$. Moreover, the CLA expression was evaluated in order to identify the presence of activated skin-homing cells in the cutaneous infiltrate. Five-microns sections were mounted on glass slides coated with poly-1lysine(Poly-L-Lysine, Sigma, USA, CAT\# P8920) and deparaffinized. Inhibition of endogenous peroxidase was obtained with $\mathrm{H} 2 \mathrm{O} 2$ solution 3\%. Antibodies were applied as indicated in Table 1. Antigen retrieval was performed according to manufacturer instructions for each antibody. Streptavidin-biotin system (Dako LSAB, CAT\# K0690) was used in additional steps [22]. Whenever necessary, tissue sections were washed with PBS-TWIN20. Diaminobenzidine (Dako, USA, cat\# K3466) was used as chromogen and sections were counterstained with Harris haematoxilyn. Positive cells were identified and quantified, in at least 12 fields in each section, and expressed as the number of identified cells per counted fields of the light microscope section, using a 50X objective (Olympus BX51, 500x augmentation). Histological evaluation was carried out by 2 independent evaluators. 
Table 1. Description of the Monoclonal Antibodies Used in this Investigation

\begin{tabular}{|c|c|c|c|c|c|}
\hline Ac Code & Ac Monoclonal & Specificity & Dilution & Source & $\begin{array}{l}\text { Time of } \\
\text { Incubation }\end{array}$ \\
\hline CD1a & Monoclonal mouse anti-CD1a, clone 010 , IgG1 & Langerhans cells & $1: 50$ & *Dako & 1 hour \\
\hline $\mathrm{CD} 8$ & Monoclonal mouse Ac anti-CD8, clone C8/144B, IgG1 & T-Cytotoxic Lymphocytes & $1: 50$ & Dako & 1 hour \\
\hline CD3 & Policlonal rabbit anti-human CD3 & CD3 in T cells & $1: 500$ & Dako & 1 hour \\
\hline $\mathrm{CD} 4$ & Monoclonal Ac to CD4 (Mouse IgG1-clone 4B12) & T-helper Lymphocytes & $1: 30$ & BioGenex & 1 hour \\
\hline CLA & $\begin{array}{l}\text { Purified Rat anti-human CLA monoclonal Ac } \\
\text { (IgM)- Clone HECA-452 }\end{array}$ & CLA & $1: 50$ & $\begin{array}{l}\text { BD Biosciences } \\
\text { Pharmigen }\end{array}$ & 1 hour \\
\hline
\end{tabular}

* Dako Corporation-California-USA.

\section{Statistic Analysis}

The statistic analysis was tested by Wilcoxon test (nonparametric) to verify any significant variation regarding the number of CD1a+, CD8+, CD3+, CD4+ and CLA+ cells between the active border and the non-lesional skin in vitiligo patients. Mann-Whitney test (non-parametric) was used in order to verify if there was any significant difference in the counting of positive cells $(\mathrm{CD} 1 \mathrm{a}, \mathrm{CD} 8, \mathrm{CD} 3, \mathrm{CD} 4$ and CLA) between cases and controls. The criteria for significance was the level of $5 \%$ (whenever $p$ value $\leq 0.05$, there was statistic significance). The statistical analysis was assessed by the statistic software $\mathrm{SAS}^{\mathbb{B}}$ System 6.04.

\section{RESULTS}

We found no statistically significant variation in the total number of counted cells CD1a+ $(\mathrm{p}=0,06), \mathrm{CD} 8+(\mathrm{p}=0,86)$, CD4+ $(p=0,19), \quad C D 3+(p=0,88)$, nor CLA $+(p=0,31)$, comparing the active border $(\mathrm{AB})$ and the non-lesional skin (NL skin) of vitiligo patients. However, comparing separately their epidermis and dermis between those distinct skin segments, we observed a statistically significant increase in the intraepidermal CD8 $+\mathrm{T}$ lymphocytes counting $(p=0.044)$ and $C D 3+T$ cells $(p=0.033)$ in the active border in comparison to NL skin.

A second analysis was made comparing the skin biopsies of vitiligo patients with the skin of control individuals. The main immunohistochemical findings are described in Table 2. Compared to normal controls, we found a significant depletion of CD1 a + cells in the total skin (sum of epidermis + dermis), in both $\mathrm{AB}$ and NL segments (Fig. 1) of the patients, mainly due to significant reduction of the CD1a+ cells number in the epidermis. There was a significant increase in the number of $\mathrm{CD} 8+\mathrm{T}$ lymphocytes in the epidermis and dermis in the active border of lesions. In contrast, in the NL skin of vitiligo, such a significant increase was only observed in the dermis, compared to normal controls (Fig. 2). The CD4+ T lymphocytes count did not show any significant alteration in the epidermis nor in the dermis, in none of the evaluated segments (AB and NL skin). There was a significant increase in $\mathrm{CD} 3+\mathrm{T}$ lymphocytes in the epidermis of the active border and NL skin of the patients. Furthermore, there was no significant alteration in the CLA+ cells count in the epidermis, nor in

Table 2. Study of the Mean Cellular Densities (Cells Per Counted Fields) in the Active Border of Depigmenting Lesions and NonLesional Skin in Vitiligo Patients Compared with the Cellularity in Controls

\begin{tabular}{|c|c|c|c|c|c|c|}
\hline $\begin{array}{l}\text { Anti } \\
\text { Body }\end{array}$ & $\begin{array}{l}\text { Active Border } \\
\text { Epidermis }\end{array}$ & $\begin{array}{l}\text { Non-Lesional } \\
\text { Epidermis }\end{array}$ & Active Border Dermis & Non-Lesional Dermis & $\begin{array}{c}* \text { Total Cells Per } \\
\text { Counted Fields } \\
\text { Lesional Skin }\end{array}$ & $\begin{array}{c}* \text { Total Cells } \\
\text { Per Counted Fields } \\
\text { Non-Lesional Skin }\end{array}$ \\
\hline CD1a & $\begin{array}{l}\text { case: } 1.78 \pm 0.77 \\
\text { Controls: } 3.84 \pm 1.14 \\
\mathbf{p}=\mathbf{0 . 0 0 0 1}\end{array}$ & $\begin{array}{l}\text { Case: } 2.00 \pm 0.95 \\
\text { Controls: } 3.84 \pm 1.14 \\
\mathbf{p}=\mathbf{0 . 0 0 0 4}\end{array}$ & $\begin{array}{l}\text { Case: } 0.24 \pm 0.19 \\
\text { Controls: } 0.18 \pm 0.13 \\
\mathbf{p}=\mathbf{0 . 4 4}\end{array}$ & $\begin{array}{l}\text { Case: } 0.32 \pm 0.23 \\
\text { Controls: } 0.18 \pm 0.13 \\
\mathbf{p}=\mathbf{0 . 1 2}\end{array}$ & $\begin{array}{l}\text { Case: } 2.02 \pm 0.81 \\
\text { Controls: } 4.03 \pm 1.22 \\
\mathbf{p}=\mathbf{0 . 0 0 0 1}\end{array}$ & $\begin{array}{l}\text { Case: } 2.31 \pm 1.04 \\
\text { Controls: } 4.03 \pm 1.22 \\
\mathbf{p}=\mathbf{0 . 0 0 0 8}\end{array}$ \\
\hline CD8 & $\begin{array}{l}\text { Case: } 0.21 \pm 0.35 \\
\text { Controls: } 0.03 \pm 0.07 \\
\mathbf{p}=\mathbf{0 . 0 2 3}\end{array}$ & $\begin{array}{l}\text { Case: } 0.08 \pm 0.19 \\
\text { Controls: } 0.03 \pm 0.07 \\
p=0.22\end{array}$ & $\begin{array}{l}\text { Case: } 2.05 \pm 1.53 \\
\text { Controls: } 1.06 \pm 0.81 \\
\mathbf{p}=\mathbf{0 . 0 2 5}\end{array}$ & $\begin{array}{l}\text { Case: } 2.21 \pm 1.06 \\
\text { Controls: } 1.06 \pm 0.81 \\
\mathbf{p}=\mathbf{0 . 0 0 8}\end{array}$ & $\begin{array}{l}\text { Case: } 2.26 \pm 1.68 \\
\text { Controls: } 1.09 \pm 0.87 \\
\mathbf{p}=\mathbf{0 . 0 1 1}\end{array}$ & $\begin{array}{l}\text { Case: } 2.29 \pm 1.44 \\
\text { Controls: } 1.09 \pm 0.87 \\
\mathbf{p = 0 . 0 0 6}\end{array}$ \\
\hline CD4 & $\begin{array}{l}\text { Case: } 0.11 \pm 0.45 \\
\text { Controls: } 0.01 \pm 0.03 \\
p=0.93\end{array}$ & $\begin{array}{l}\text { Case: } 0.16 \pm 0.32 \\
\text { Controls: } 0.01 \pm 0.03 \\
p=0.27\end{array}$ & $\begin{array}{l}\text { Case: } 3.85 \pm 3.0 \\
\text { Controls: } 3.13 \pm 1.75 \\
p=0.68\end{array}$ & $\begin{array}{l}\text { Case }: 2.55 \pm 1.56 \\
\text { Controls: } 3.13 \pm 1.75 \\
p=0.4\end{array}$ & $\begin{array}{l}\text { Case: } 3.96 \pm 3.26 \\
\text { Controls: } 3.14 \pm 1.76 \\
p=0.68\end{array}$ & $\begin{array}{l}\text { Case: } 2.72 \pm 1.69 \\
\text { Controls: } 3.14 \pm 1.76 \\
p=0.54\end{array}$ \\
\hline CD3 & $\begin{array}{l}\text { Case: } 0.4 \pm 0.56 \\
\text { Controls: } 0.006 \pm 0.02 \\
\mathbf{p}=\mathbf{0 . 0 0 2}\end{array}$ & $\begin{array}{l}\text { Case: } 0.14 \pm 0.25 \\
\text { Controls: } 0.006 \pm 0.02 \\
\mathbf{p}=\mathbf{0 . 0 0 7}\end{array}$ & $\begin{array}{l}\text { Case: } 4.17 \pm 4.33 \\
\text { Controls: } 2.74 \pm 1.41 \\
p=0.38\end{array}$ & $\begin{array}{l}\text { Case: } 3.78 \pm 2.2 \\
\text { Controls: } 2.74 \pm 1.41 \\
p=0.23\end{array}$ & $\begin{array}{l}\text { Case: } 4.58 \pm 4.63 \\
\text { Controls: } 2.74 \pm 1.42 \\
p=0.24\end{array}$ & $\begin{array}{l}\text { Case: } 3.93 \pm 2.35 \\
\text { Controls: } 2.74 \pm 1.42 \\
p=0.22\end{array}$ \\
\hline CLA & $\begin{array}{l}\text { Case: } 0.28 \pm 0.57 \\
\text { Controls: } 0.23 \pm 0.26 \\
p=0.51\end{array}$ & $\begin{array}{l}\text { Case: } 0.04 \pm 0.09 \\
\text { Controls: } 0.23 \pm 0.26 \\
\mathbf{p}=\mathbf{0 . 0 3 5}\end{array}$ & $\begin{array}{l}\text { Case: } 4.7 \pm 2.16 \\
\text { Controls: } 3.37 \pm 1.99 \\
p=0.086\end{array}$ & $\begin{array}{l}\text { Case: } 4.35 \pm 2.15 \\
\text { Controls: } 3.37 \pm 1.99 \\
p=0.22\end{array}$ & $\begin{array}{l}\text { Case: } 4.98 \pm 2.35 \\
\text { Controls: } 3.6 \pm 2.17 \\
p=0.065\end{array}$ & $\begin{array}{l}\text { Case: } 4.4 \pm 2.15 \\
\text { Controls: } 3.6 \pm 2.17 \\
p=0.31\end{array}$ \\
\hline
\end{tabular}

*Total cells (sum of epidermis and dermis cells). 
the dermis, in the $\mathrm{AB}$ of vitiligo compared to controls. In NL skin, the CLA+ cell numbers were reduced in the epidermis in comparison to controls.
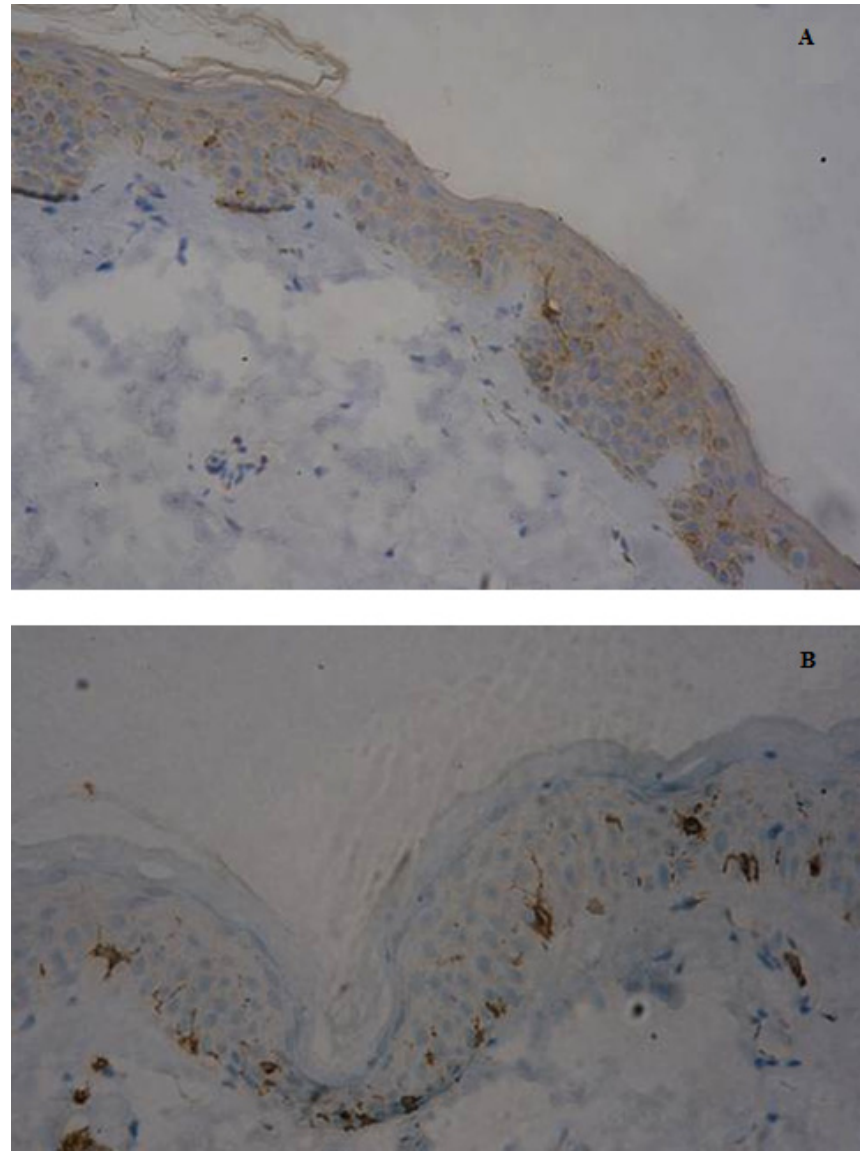

Fig. (1). Significantly decreased number of CD1 a positive cells (in brown) in the non-lesional skin (A) of active vitiligo patients. In contrast, there are abundant marked CD1a positive cells in the control skin (B). 100X augmentation.

\section{DISCUSSION}

The majority of the immunohistochemical studies published, including active border and/or perilesional skin and non-lesional skin of vitiligo patients, did not report a significant involvement of their clinically normal skin in the context of its cellularity. Some authors emphasized the findings of activated epidermal CD8-CLA $+\mathrm{T}$ cells in apposition to melanocytes only in the lesional sites $[10,11$, $16]$.

One research showed a microdepigmentation in nonlesional skin of vitiligo patients by immunohistochemical methods in 2 cases of active vitiligo. Although the study has included a small number of patients $(n=5)$, the authors clearly demonstrated the immunopolarization of $\mathrm{T}$ cells towards type-1-like cytokines profile [12]. Previously, other authors identified many histological changes in the clinically normal skin of vitiligo patients by optic and electronic microscopy, such as vacuolization of the basal layer, mononuclear infiltrate, degenerated melanocytes, dermal melanophages, vacuolized keratinocytes and extracellular granular material. However, they did not focus on comparing their findings with the active lesions [15, 23-25].
Strikingly, in the present study there was no statistically significant variation in the total number of counted $\mathrm{CD} 1 \mathrm{a}^{+}$, $\mathrm{CD} 8+, \mathrm{CD} 4+, \mathrm{CD} 3+$, nor CLA+ cells comparing the active border of vitiligo lesions and the non-lesional skin of vitiligo patients. Additionally, comparing separately the number of those cells in the epidermis and dermis in those distinct skin segments (AB and NL skin) to controls, the major difference was a significant increase in the intraepidermal CD8+ $\mathrm{T}$ lymphocytes only in the active border of vitiligo lesions. Such findings suggest a pivotal role for the CD8+ T lymphocytes in the melanocytes loss, since their epidermal infiltration has been evident in a few active lesions correlated with clinical depigmentation, whilst we did not observe those lymphocytes invading the epidermis in any clinically pigmented area. This is in agreement with previous immunohistochemical studies that showed a dermal and/or epidermal infiltrate of $\mathrm{T}$ lymphocytes in progressively depigmented macules [10, 26, 27], sometimes in parallel with the disappearance of melanocytes $[11,12,16]$, and in cases of inflammatory vitiligo in which such infiltrates are more easily characterized [28].
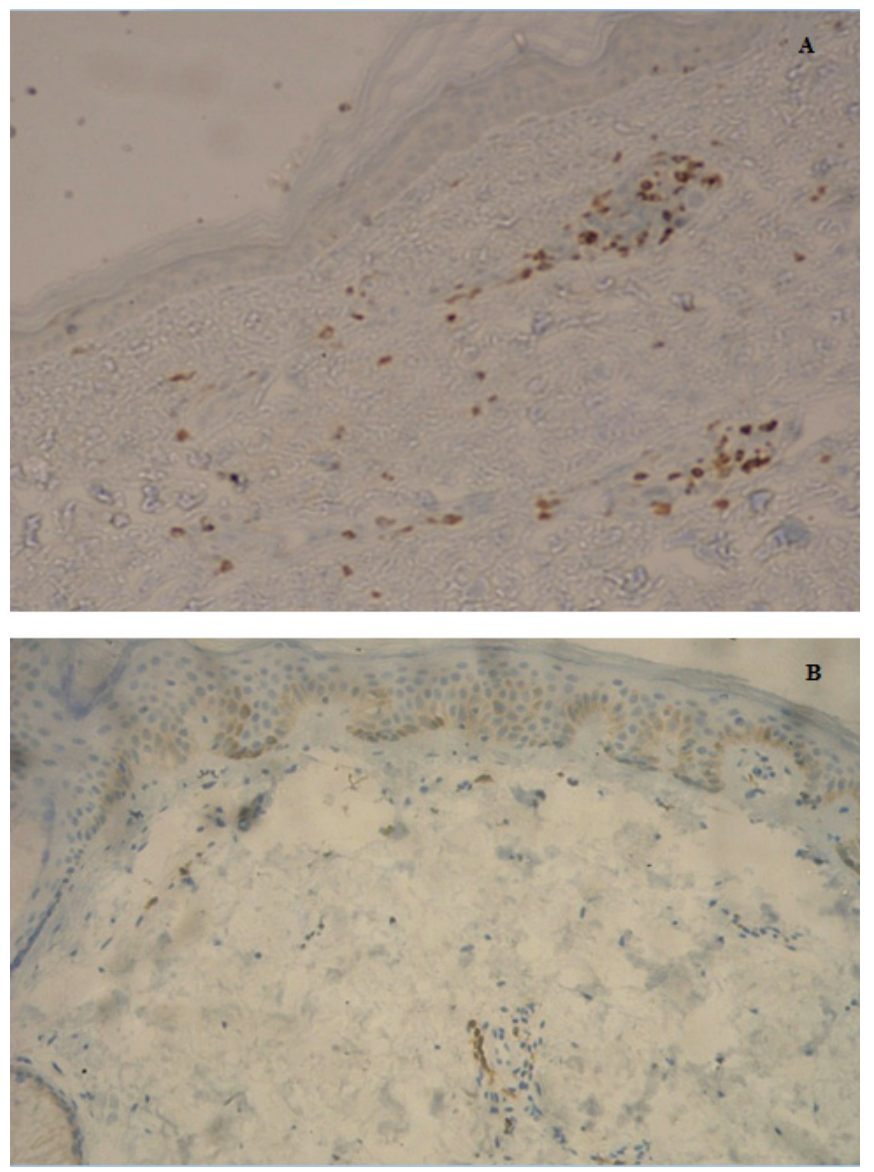

Fig. (2). Presence of $\mathrm{CD} 8+$ cells infiltrate in the dermis of nonlesional skin in active vitiligo (A). Such infiltrate was not observed in any control skin (B). 100X augmentation.

Regarding the changes of CD4+ $\mathrm{T}$ lymphocytes, the number of these cells did not vary significantly between patients and controls in any analyzed sector of their skin. This is in contrast to Wankowicz-Kalinska et al. [12].

Interestingly, we found a scarcity of the cells that expressed the CD1a marker in both, active border and NL 
skin of vitiligo patients, whilst such findings have never been observed in the normal controls in the present study. Although we could not establish precisely if there was a real depletion of Langerhans cells (LC), because a loss of the marker may occur without the loss of corresponding cells, the reduced expression of the CDla suggests some role of the $\mathrm{LC}$ in vitiligo. The $\mathrm{LC}$ are specialized antigen-presenting cells, that inhabit mainly in a high level of the supra-basal epidermis, constitute about $2 \%$ to $4 \%$ of the epidermal cells [29] and uniquely capable of activating naive $T$ cells in lymph nodes. Their exit from the epidermis can be strongly augmented by inflammatory or danger signals in the periphery, provided by cytokines (mainly TNF-alfa and IL1beta), microbes and others. Some few LC are present in the dermis of the normal skin. LC in the dermis may represent cells that have emigrated upon capturing antigen in the epidermis and are on their way to the lymph node [29, 30]. Other authors also found a deep depletion of LC in active vitiligo and attributed this finding to two factors: 1) destruction of these cells for cytotoxic factors during the destruction of melanocytes; 2) migration of these cells from the epidermis to regional lymph nodes to present certain antigens when the destruction of melanocytes is triggered in the period of disease activity [31]. Furthermore, a functional impairment of LC in vitiligo has already been suggested by a weaker hypersensitivity response to dinitrochlorobenzene in vitiliginous skin compared with non-lesional skin in vitiligo patients [32, 33]. However, we demonstrated a reduced number of LC in both, lesional and non-lesional skin of our patients, similarly to other studies $[11,33]$. Therefore, the exact role of the $\mathrm{LC}$ in the pathogenesis of vitiligo still remains an enigma [7, 34].

The absence of statistically significant expression of CLA + cells in both, active border and NL skin, can be explained by the reduction of the cells that expressed the CD1a marker, which can also be CLA+ $[35,36]$. Van den Wijngaard et al. detected CLA $+\mathrm{T}$ cells as clusters at the dermo-epidermal junction, where melanocytes were in process of disappearing in active vitiligo [11]. However, the total percentage of those skin-homing cells was not increased when compared to controls. Similarly, we also observed such localized clusters of CLA+ cells, although their number has not been significantly increased. Regarding the diminished number of CLA+ cells in the non-lesional epidermis compared to controls, this has probably occurred due to the reduced number of Langerhans cells in that site [36]. A few studies have strengthened the idea of a recruitment of CLA+ cells from the peripheral circulation to the skin, in order to participate in the immune reaction $[10,11,16,36,37]$. Further studies using double-label immunohistochemistry would better differentiate which cellular populations composed that infiltrate, and which of them were activated.

More recently, others authors have demonstrated surprising changes involving the non-lesional skin of vitiligo patients. Kingo et al. [38] showed an increased expression of the genes of the intracellular melanogenesis pathway in the non-lesional skin of vitiligo patients. Ardigo et al. [39] used the reflectance confocal microscopy, which is based on the different light reflectance index of cutaneous structures, allowed in vivo, en face microscopic evaluation of superficial skin layers with a resolution similar to skin histology. They showed unexpected changes in the non-lesional skin of vitiligo patients, such as the presence of half-rings or scalloped border-like features of the bright papillary rings, in contrast with the bright rings normally seen at the dermoepidermal junction.

In conclusion, added to previous histological reports, the immunohistochemical cellular findings in the present study suggest an active cellular immune response (initial?) including the apparently normal skin of vitiligo patients. In other words, the clinically pigmented skin would also be somehow immune-committed in the active vitiligo, and some specific cellular event might eventually occur in the epidermis, previously to the clinically detectable depigmentation. What possible "protective" events could avoid the appearance of new lesions in some areas of the integument remain unclear. This study adds some support to an autoimmnune hypothesis and a pivotal role of CD8+ T cells and LCs in the context of melanocyte loss. Further studies are necessary to clarify the complex mechanisms involved in the pathogenesis of vitiligo.

\section{REFERENCES}

[1] Njoo MD, Westerhof W. Vitiligo pathogenesis and treatment. Am J Clin Dermatol 2001; 2: 167-81.

[2] Njoo MD, Bos JD, Westerhof W. Treatment of generalized vitiligo in children with narrow-band (TL-01) UVB radiation therapy. J Am Acad Dermatol 2000; 42: 245-53.

[3] Kovacs SO. Vitiligo. J Am Acad Dermatol 1998; 38: 647-66.

[4] Alkhateeb A, Fain PR, Thody A, Bennett DC, Spritz RA. Epidemiology of vitiligo and associated autoimmune diseases in Caucasian probands and their husbands. Pigment Cell Res 2003; 16: 208-14.

[5] Laberge G, Mailloux CM, Gowan K, et al. Early disease onset and increased risk of other autoimmune diseases in familial generalized vitiligo. Pigment Cell Res 2005; 18: 300-5.

[6] Farrokhi S, Hojjat-Farsangi M, Noohpisheh MK., Tahmasbi R, Rezaei N. Assessment of the immune system in 55 Iranian patients with vitiligo. J Eur Acad Dermatol Venereol 2005; 19: 706-11.

[7] Ongenae K, Geel NV, Naeyaert JM. Evidence for autoimmune pathogenesis of vitiligo. Pigment Cell Res 2003; 16: 90-100.

[8] Jin Y, Mailloux CM, Gowan K, et al. NALP1 in vitiligo-associated multiple autoimmune disease. N Engl J Med 2007; 356: 1216-25.

[9] Tu CX, Gu JS, Lin XR. Increased interleukin-6 and granulocytemacrophage colony stimulating factor levels in the sera of patients with non-segmental vitiligo. J Dermatol Sci 2003; 31: 73-8.

[10] Al Badri AMT, Todd PM, Garioch JJ, Gudgeon JE, Stewart DG, Goudie RB. An immunological study of cutaneous lymphocytes in vitiligo. J Pathol 1993; 170: 149-55.

[11] Van den Wijngaard R, Wañkowicz-Kaliñska A, Le Poole C, Tigges B, Westerhof W, Das PK. Local immune response in skin of generalized vitiligo patients. Destruction of melanocytes is associated with the proeminent presence of CLA+T cells at the perilesional site. Lab Invest 2000; 80: 1299-309.

[12] Wankowicz-Kalinska A, Van den Wijngaard RM, Tigges BJ, et al. Immunopolarization of CD4+ and CD8 + T cells to type-1-like is associated with melanocyte loss in human vitiligo. Lab invest 2003; 83: 683-95.

[13] Le Poole IC, Wankowicz-kalinska A, Van den Wijngaard RM, Nickoloff BJ, Das PK. Autoimmune aspects of depigmentation in vitiligo. J Investig Dermatol Symp Proc 2004; 9: 68-72.

[14] Ogg GS, Rod Dunbar P, Romero P, Chen JL, Cerundolo V. High frequency of skin-homing melanocyte-specific cytotoxic T lymphocytes in autoimmune vitiligo. J Exp Med 1998; 188: 12038.

[15] Hann SK, Park YK, Lee KG, Choi EH, Im S. Epidermal changes in active vitiligo. J Dermatol 1992; 19: 217-22.

[16] Le Poole IC, Van den Wijngaard RM, Westerhof W, Das PK. Presence of $\mathrm{T}$ cells and macrophages in inflammatory vitiligo skin parallels melanocyte disappearance. Am J Pathol 1996; 148: 121928.

[17] Das PK, Van den Wijngaard RM, Wankowicz-kalinska A, Le Poole IC. A symbiotic concept of autoimmunity and tumour 
autoimmunity: Lessons from vitiligo. Trends Immunol 2001; 22: 130-6.

[18] Becker JC, Guldberg P, Zeuthen J, Brocker EB. Straten PT. Accumulation of identical $\mathrm{T}$ cells in melanoma and vitiligo-like leukoderma. J Invest Dermatol 2002; 113: 1033-38.

[19] Sweet RD. Vitiligo as a Koebner phenomenon. Br J Dermatol 1978; 99: 223-4.

[20] Bos JD, Hulsebosch HJ, Krieg SR, Bakker PM, Cormane RH. Immunocompetent cells in psoriasis. In situ immunophenotyping by monoclonal antibodies. Arch Dermatol Res 1983; 275: 181-9.

[21] Pretti Aslanian FM, Noe RA, Cuzzi T, Filgueira AL. Abnormal histological findings in active vitiligo include the normal-appearing skin. Pigment Cell Res 2007; 20(2): 144-5.

[22] Hsu SM, Raine L. Protein A, avidin, and biotin in immunohistochemistry. J Histochem Cytochem 1981; 29: 1349-53.

[23] Moellmann G, Klein-Angerer S, Scollay DA, Nordlund JJ, Lerner AB. Extracellular granular material and degeneration of keratinocytes in the normally pigmented epidermis of patients with vitiligo. J Invest Dermatol 1982; 79: 321-30.

[24] Bhawan J, Bhutani LK. Keratinocyte damage in vitiligo. J Cutan Pathol 1983; 10: 207-12.

[25] Mosher DB, Fitzpatrick TB, Ortonne JB, Hori Y. Hypomelanoses and hypermelanoses. In: Freedberg IM, Eisen AZ, Wolff $\mathrm{K}$ et al, Eds. Dermatology In General Medicine. New York, Mcgraw-Hill 1999; 945-1017.

[26] Nordlund JJ, Lerner AB. Vitiligo. It is important. Arch Dermatol 1982; 118: 5-8.

[27] Ahn SK, Choi EH, Lee SH, Won JH, Hann SK, Park YK. Immunohistochemical studies from vitiligo- comparison between active and inactive lesions. Yonsei Med J 1994; 35: 404-10.

[28] Hann SK, Kim YS, Yoo JH, Chun YS. Clinical and histopathologic characteristics of trichrome vitiligo. J Am Acad Dermatol 2000; 242: 589-96.
[29] Robert C, Kupper TS. Inflammatory skin diseases, T cells and immune surveillance. N Engl J Med 1999; 341: 1817-28.

[30] Teunissen MBM. Langerhans cells and other skin dendritic cells. In: Bos JD, Ed. Skin Immune System Cutaneous Immunology and Clinical Immunodermatology. New York, CRC Press 2005; 123 82

[31] Kao CH, Yu HS. Depletion and repopulation of Langerhans cells in nonsegmental type vitiligo. J Dermatol 1990; 17: 287-96.

[32] Uehara M, Miyauchi H, Tanaka S. Diminished contact sensitivity response in vitiliginous skin. Arch Dermatol 1984; 120: 195-8.

[33] Hatchome N, Aiba S, Kato T, Torinuki W, Tagami H. Possible functional impairment of Langerhans' cells in vitiliginous skin. (Reduced ability to elicit dinitrochlorobenzene contact sensitivity reaction and decreased stimulatory effect in the allogeneic mixed skin cell lymphocyte culture reaction). Arch Dermatol 1987; 123: 51-4.

[34] Castanet J, Ortonne JP. Immunology of vitiligo. In: Bos JD. Skin Immune System (SIS). New York, CRC Press 1997; 543-53.

[35] Hunger RE, Yawalkar N, Braathen LR, Brand CU. The HECA-452 epitope is highly expressed on lymph cells derived from human skin. Br J Dermatol 1999; 141: 565-9.

[36] Santamaria-Babi LF. CLA+ T cells in cutaneous diseases. Eur J Dermatol 2004; 14: 13-18

[37] Lee DJ, Modlin RL. Breaking tolerance- another piece added to the vitiligo puzzle. J invest Dermatol 2005; 124: xiii-xv.

[38] Kingo K, Aunin E, Karelson M, et al. Expressional changes in the intracellular melanogenesis pathways and their possible role the pathogenesis of vitiligo. J Dermatol Sci 2008; 52: 39-46.

[39] Ardigo M, Malizewsky I, Dell'anna ML, Berardesca E, Picardo M. Preliminary evaluation of vitiligo using in vivo reflectance confocal microscopy. J Eur Acad Dermatol Venereol 2007; 21: 1344-50.

(C) Aslanian et al.; Licensee Bentham Open.

This is an open access article licensed under the terms of the Creative Commons Attribution Non-Commercial License (http://creativecommons.org/licenses/by$\mathrm{nc} / 3.0 /$ ) which permits unrestricted, non-commercial use, distribution and reproduction in any medium, provided the work is properly cited. 